\title{
Klausul Tanggung Jawab Sosial Dan Lingkungan Dalam Akta Notaris Sebagai Upaya Pengembangan Perusahaan Terbatas (PT) Pada Era Globalisasi Oleh : Elita Rahmi.Ageng Triganda Sayuti, Zulfadli
}

\begin{abstract}
Abstrak
Belum ditemukan akta Perusahaan Terbatas (PT) dalam mencantumkan kesadaran lingkungan berupa tanggung jawab sosial dan lingkungan pada akta pendirian PT dan Anggaran Dasar Perusahaan Terbatas (PT), sehingga terkesan tanggung jawab sosial perusahaan atau lebih dikenal dengan CSR terkesan pengeluaran biaya (cost center) perusahaan, karena adanya tekanan luar yakni berbagai peraturan perundangan dan kebijakan pemerintah dan tekanan globalisasi yang mewajibkan hal tersebut. Padahal klausul pendirian dan perubahan PT yang dapat menjadi agenda pada saat pendirian dan RUPS sangat memungkinkan dapat dimuat oleh Notaris melalui kewajibannya memberikan penyuluhan hukum dan keinginan perusahaan untuk menyadari bahwa kesadaran perusahaan atas lingkungan yang baik dan sehat adalah bagian yang melekat atas kehadiran perusahaan di muka bumi (kewajiban hukum dan moral). Tujuan Penelitian ini adalah : Pertama :Untuk menjadikan kesadaran lingkungan sebagai suatu peryataan kesadaran perusahaan dalam mewujudkan tanggung jawab sosial dan lingkungan perusahaan sebagai kewajiban hukum perusahaan Kedua untuk meningkatkan peran perusahaan dalam pembangunan berkelanjutan sebagai suatu kewajiban moral. Metode Penelitian yang digunakan adalah yuridis normative dengan menjadikan akta notaris pada pendirian atau perubahan Anggaran Dasar sebagai ruang yang sangat memungkinkan notaris dan perusahaan dapat membangun kesadaran hukum melalui keadilan lingkungan, dengan pendekatan historis, dan pendekatan perundang-undangan serta pendekatan konsep yang diperolah melalui bahan hukum primer, sekunder dan tersier, maka teknik pengumpulan bahan hukum yang dipergunakan adalah, menginventarisir, ketentuan Anggaran Dasar perusahaan untuk dilakukan klasipikasi dan sistematisasi dan selanjutnya dengan mengunakan interpretasi, maka dilakukan analisis, sesuai dengan perkembangan hukum perusahaan dan hukum lingkungan serta peran notaris sebagai pejabat umum yang melaksanakan sebagian tugas pemerintah dalam mendorong perusahaan guna menjalankan kewajikannya melalui prinsip-prinsip pembangunan berkelanjutan yakni mewujudkan lingkungan hidup yang baik dan sehat. Kesimpulan penelitian ini menunjukkan, pertama: bahwa fungsi klausul tanggung jawab sosial dan perusahaan tetap harus didorong dalam prosedur peraturan perundang-undangan terutama di daerah berupa perda dan kebijakan lainnya serta Ikatan Notaris Indonesia (INI) untuk selalu memberikan rambu-rambu bagi anggotanya dalam pengembangan akta perusahaan sebagai tanggung jawab hukum dan moral INI dalam mengembangkan prinsip-prinsip moral notaris dalam pembuatan akta .Kedua Pembangunan berkelanjutan bagi perusahaan yang ada di indonesia belum menjadi instrumen dasar bagi perusahaan untuk berbagi keuntungan karena masih dipandang memberatkan perusahaan, dan prosedur perizinan yang menjadi kewenangan pememerintah daerah selaku eksekutor dalam mengawasi klausul tanggung jawab sosial sebagai instrumen lingkungan dalam mewujudkan lingkungan yang baik dan sehat sebagai ujung tombak pembangunan.
\end{abstract}

Kata Kunci: Klausul Tanggung Jawab Sosial dan Lingkungan, Pengembangan PT, Globalisasi 


\begin{abstract}
There is not much awareness of Limited Liability Company (PT) in including environmental awareness in the form of social and environmental responsibility in the PT establishment deed, especially in the PT Articles of Association, so that it appears that corporate social responsibility, better known as CSR, is "forced" by the company, due to pressure outside of various regulations and government policies. Even though the establishment and change clauses of PT that can be a very large RUPS agenda can be published by a Notary by building the company's awareness of a good and healthy environment. The objectives of this study are: First: To make environmental awareness a statement of company awareness in realizing corporate social and environmental responsibility as a second corporate obligation to enhance the company's role in sustainable development. The research method used is normative jurid by making a notary deed in the establishment or amendment of the Articles of Association as a space that allows notaries and companies to build legal awareness through environmental justice, historical approaches, and legislative approaches and conceptual approaches obtained through primary legal material, secondary and tertiary, the legal materials collection technique used is, inventory, provisions of the Articles of Association for classi fi cation and systematization and then by using interpretations, an analysis is carried out, in accordance with the development of company law and environmental law and the role of notary public part of the government's duty to encourage companies to carry out their virtues through the principles of sustainable development, namely to realize a good and healthy environment. The conclusion of this study shows, that the function of social responsibility clauses and companies must still be encouraged in the regulatory procedures in the form of regulations and government policies to involve notaries including the clauses of social and environmental responsibility in managing existing licenses. Second Continuous development has not become a basic instrument for companies to share profits because it is still considered burdensome to the company, so that licensing procedures that are under the authority of the local government are executors in overseeing social responsibility clauses as environmental instruments that can create a good and healthy environment. spear of development.
\end{abstract}

\title{
Keywords: Social and Environmental Responsibility Clause, PT Development, Globalization
}

\section{PENDAHULUAN}

Paradikma tujuan perusahaan yang semata-mata mencari keuntungan (money) dalam perkembangannya telah mengalami pergeseran baik dalam dunia bisnis maupun tuntutan persaingan usaha yang sehat, tanpa disadari sangat mudah isu-isu lingkungan untuk dapat dihembuskan dalam rangka menilai produk yang tidak taat asas terhadap instrumen lingkungan yang baik dan sehat.

Perusahaan yang lalai atau sengaja tidak mau tahu dengan ekosistem lainnya, akan semakin sulit berkompetisi di dunia bisnis. Contoh isu kelangkaan harimau atau gajah 
dengan istilah "gajah mengamuk" atau "harimau masuk kampong", akibat habitatnya terganggu, atau kerusakan benda cagar budaya, atau konflik suku anak dalam, akibat semakin menyempit hunian mereka, adalah isu yang dapat menurunkan daya beli pasar pada era globalisasi. Artinya respon pasar terhadap kerusakan lingkungan sangat positip, dan akhirnya perusahaanpun akan kolep (pailit), atau setidak-tidaknya produknya dapat kurang diminati pasar.

Seorang notaris memiliki kewajiban untuk tidak hanya menjadikan akta notaris hanya sekedar seremonial belaka, tetapi seorang notaris yang profesional juga dituntut menemukan klausul-klausul yang memungkinkan suatu perusahaan bertahan hidup (survive) dalam persaingan bisnis yang sangat kompetitif yakni bersaingan tehnologi dan persaingan mutu serta care dengan alam dan lingkungan, disamping mengalami prinsip-prinsip kehati-hatian (prudential principle $)^{1}$ dalam membuat akta autentik

Bermunculnya standar lingkungan ISO 9000 atau ISO $26000^{2}$, dan dicantumkannya kepatuhan standar tersebut dalam setiap produk membuktikan bahwa kebutuhan pasar tidak semata-mata hanya kualitas produk, tetapi bagaimana standar-standar baku mutu lingkungan dipatuhi oleh perusahan sebagai suatu kewajiban yang menyertai produk. Ditemui adanya tautan antara green legislation, dan green budgeting dalam tata kelola perusahaan yang baik.

Hal di atas, tentu juga harus disadari oleh para perusahaan dan para notaris untuk menjadikan akta notaris baik itu akta pendirian maupun akta perubahan yang biasanya

\footnotetext{
${ }^{1}$ Ida Bagus Paramaningrat Manuaba, I Wayan Parsa, I Gusti Ketut Ariawan, Prinsip Kehati-hatian Notaris Dalam membuat Akta Autentik, Jurnal Acta Comitas(2018)1:59-74.ISSN 2502-8960 I e-ISSN:2502-7573.HIm 59-76.

${ }^{2}$ Elita Rahmi, Standarisasi Lingkungan (ISO 26000) Sebagai Harmonisasi Tanggung Jawab Sosisl Perusahaan dan Intrumen Hukum Indonesia, Inovatif Jurnal Ilmu HUkum, Vol 4 No 5 (2011).
} 
dibuat dalam rangka mengakomodasikan tuntutan perusahaan dan tuntutan dunia usaha yang semakin hari semakin mengemuka.

Adanya perbedaan antara tanggung jawab sosial merupakan kewajiban ${ }^{3}$ di Indonesia dan tanggung jawab sosial sebagai suatu perbuatan sukarela di negara lainnya, menunjukkan bahwa kesadaran hukum perusahaan di Indonesia , memang harus didorong oleh perangkatperangkat hukum perusahaan yang memungkinkan perusahaan tersebut dapat berkembang pesat, karenaya fungsi negara Indonesia sebagai suatu negara kesejahteraan, peran negara dan pemerintah atau masyarakat, diantaranya melalui akta perusahaan sebagai suatu dokumen dasar perusahaan. Dapat memberi ruang dalam mewujudkan pasal 28 H.UUD 1945 ayat (1) yakni memberikan landasan bahwa mendapatkan lingkungan hidup yang baik dan sehat merupakan hak setiap orang dan menjadi kewajiban perusahaan untuk mengelola perusahaan dengan menggunakan prinsip-prinsip pembangunan berkelanjutan sebagai upaya mewujudkan keadilan lingkungan atau keadilan ekologi ${ }^{4}$.

Salah satu perbuatan hukum yang diharuskan peraturan perundang-undangan untuk dituangkan ke dalam akta Notaris adalah pendirian Perseroan Terbatas (PT). Menurut Pasal 7 ayat (1) Undang-Undang Nomor 40 Tahun 2007 tentang Perseroan Terbatas (UUPT), bahwa PT didirikan oleh 2 (dua) orang atau lebih dengan akta notaris yang dibuat dalam bahasa Indonesia. Dalam Akta Pendirian PT, pengaturan mengenai Anggaran Dasar merupakan hal yang utama. Sebagai roh perusahaan Anggaran Dasar dibuat dan dapat mengalami perubahan

\footnotetext{
${ }^{3}$ Kewajiban adalah keharusan untuk melakukan atau tidak melakukan sesuatu perbuatan tertenty atas tuntutan satu orang aau lebih yang berhak. Hak adalah kekuasaan dan kekuasaan ini dapat dipertahankan terhadap setiap orang, artinya setiap orang harus mengakui, menghormati, dan mengindahkan kekuasaan itu( Lihat Bachsan Mustafa, Sistem Hukum Indonesia Terpadu Citra Aditya Bakti Bandung 2016, hlm 33-34

${ }^{4}$ Maret Priyanta, Pengelolaan Hutan Berkelanjutan (Dalam Kerangka Pembaharuan Sistem Hukum Lingkungan dan Tata Ruang Berbasis Perubahan Iklim),Penerbit Logoz Publishing, Bandung,hlm 63-67.
} 
dalam rangka pengembangan perusahaan agar perusahaan tersebut dapat bertahan hidup sebagaimana sebuah badan hukum.

Sangat memungkinkan perusahaan mencantumkan kesadaran hukum akan ketaatan perusahaan akan fungsi sosial dan lingkungan dalam akta pendirian dan akta perubahan perusahaan yang dapat dikembangkan dalam Rapat Umum pemegang saham kearah kewajiban perusahaan dalam mewujudkan keadilan lingkungan melalui pembangunan berkelanjutan.

\section{Permasalahan}

Adapun yang menjadi permasalahan dalam penelitian ini adalah :

1. Bagaimana arti penting klausul tanggung jawab sosial perusahaan dalam akta notaris?

2. Bagaimana konsep klausul tanggung jawab sosial tersebut menjadi bagian penting dalam akta perusahaan dan pengembangan perusahaan dalam Anggaran Dasar dan Anggaran Rumah Tangga Perusahaan dan pembahasan pada Rapat Umum Pemegang Saham (RUPS), untuk terus diperbaharui sesuai dengan tuntutan persaingan globalisasi dan standar intrumen lingkungan yang terus meningkat?

\section{Tujuan dan Manfaat Penelitian}

\section{a. Tujuan Penelitian}

\section{Adapun Tujuan dari penelitian ini adalah :}

1. Untuk meningkatkan fungsi akta dan professional notaris dalam pembuatan akta perusahaan, sehingga notaris sebagai pejabat umum dan juga meyandang profesi mulia 
diharapkan dapat memberikan kontribusi pada akta perusahaan daam kaitannya dengan pembangunan berkelanjutn

2. Untuk mengkaji jenis-jenis akta yang dapat dimuat klausul tanggung jawab sosial perusahaan sebagai bentuk tanggung jawab perusahaan pada lingkungan hidup yang baik dan sehat, serta kedudukan RUPS dalam mengembangkan perusahaan menuju pada Good Corpotetae Covernance (GCG) atau tata kelola perusahaan yang baik

\section{b.Manfaat Penelitian}

Sedangkan manfaat penelitian adalah sbb :

Manfaat dalam perkembangan ilmu hukum khususnya dalam Hukum Perusahaan, Hukum Lingkungan dan Teknik pembuatan Akta Perusahaan serta Hukum persaingan usaha.

1. Manfaat Fungsi Akta, yang tidak hanya sekumpulan dokumen autentik administrative notaris sebagai pejabat umum tetapi juga dapat dijadikan suatu dokumen keprofesioanaln notaris sebagai suatu profesi mulia yang mempunyai tanggung jawab terhadap kelangsungan perusahaan di masa mendatang.

2. Manfaat Pengembangan perusahaan dalam rangka globalisasi, era disruption,era Revvolusi Industri 4.0.bahkan telah mencapai era 5.0 society dan era menikmati hidup dimana bukan lagi modal yang menjadi isi tetapi membantu mengisi kesenjangan antara yang kaya dan yang kurang meruntung, Tanggung jawab sosial dan lingkungan adalah sarana untuk mewujudkan era 5.0 society.

Berdasarkan tujuan dan manfaat di atas, maka penelitian ini sangat penting dilakukan guna pengembangan perusahaana di Indonesia dalam menyonsong era globalisasi yang menuntut profesionalisme dalam segala bidang, termasuk dokumen-dokuman hukum dan niat perusahaan 
untu mencerdaskan bangsa Indonesia, sebagaimana tujuan Negara RI yang tercantum dalam Pembukaan UUD 1945.

Tujuan dan manfaat ini juga akan dapat meningkatkan fungsi akta notaris sebagai suatu akta yang autentik dan mengikat para pihak untuk patuh dan taat atas hak dan kewajiban yang telah disepakati bersama.

Tujuan dan manfaat penelitian ini juga untuk mengairahkan dunia investasi, khususnya perusahaan sebagai suatu badan hukum yang dapat menjadi tolok ukur persaingan usaha yang sangat ketat pada masa yang akan datang.

\section{METODE PENELITIAN}

Penelitian ini adalah penelitian yuridis normative yang menempatkan hukum sebagai suatu sistem norma dan suatu sistem dalam perjanjian yang dimuat dalam suatu akta perusahaan baik itu akta pendirian perusahaan maupun akta perubahan perusahaan atau Anggaran Dasar dan Anggaran Rumah Tangga yang menjadi dasar lahirnya akta-akta perusahaan dan menjadi peraturan yang mengikat perusahaan untuk menjalankan hak dan kewajibannya sebagai suatu badan hukum (Subjek Hukum)

Penelitian ini menjadikan akta sebagai titik tolak atau dasar utama perusahaan yang dimuat dan di desain oleh notaris selaku pejabat umum maupun selaku orang yang sangat profesional mendesain suatu perkembangan perusahaan.

\section{a.Pendekatan penelitian}

Untuk melakukan penelitian, digunakan pendekatan sbb : 
a. pendekatan historis (Historical Approach), dilakukan dalam rangka penelusuran sejarah akta perusahaan yang terkait dengan materi muatan yang diperlukan dalam mensupport perkembangan perusahaan dan dinamika perubahan dalam era globalisasi

b. Pendekatan perundang-undangan (Statute approach), yaitu pendekatan terhadap produk hukum atau perundang-undangan yang terkait dengan hukum perusahaan dan hukum lainnya yang menunjang perusahaan sebagai suatu badan hukum.

c. Pendekatan konsep (Conceptual approach), yaitu pendekatan terhadap konsep-konsep hukum, seperti : sumber hukum, fungsi hukum, lembaga hukum dan perjanjian sebagai landasan akta notaris. Pendekatan konsep akan meneliti asas-asas hukum dan teori-teori dalam kaitannya dengan akta notaris

b.Pengumpulan Bahan Hukum

Untuk mendapatkan bahan hukum sebagai suatu penelitian normative, digunakan penelitian kepustakaan, dengan bahan hukum sbb :

1. Bahan Hukum Primer, terdiri dari peraturan perundang-undangan yang berhubungan dengan masalah yang diteliti, seperti :
a. UUD 1945

b. UU Nomor 40 Tahun 2007 tentang Perseroan Terbatas.

c. UU Nomor 32 Tahun 2009 Tentang Perlindungan dan Pengelolaan Lingkungan Hidup

d. UU Nomor 25 Tahun 2007 Tentang Penanaman Modal

e. UU Nomor 41 Tahun 1999 Tentang Kehutanan

f. Akta-akta perusahaan

2. Bahan Hukum Sekunder, memberi penjelasan mengenai bahan-bahan hukum primer, bahan hukum tersebut dapat diperoleh dari buku, jurnal-jurnal, pendapat para sarjana yang 
berhubungan dengan akta perusahaan dan kaitannya dengan tanggung jawab sosial perusahaan, karena doktrin yang berkembang dapat menjadi bahan dalam mengambil keputusan bagi pemerintah.

3. Bahan hukum tersier yakni bahan hukum yang dapat memberikan petunjuk maupun penjelasan yang bermakna terhadap bahan hukum primer dan sekunder, seperti kamus hukum, ensiklopedi, dan lain lain.

c.Teknik Pengumpulan Bahan Hukum

Bahan-bahan hukum di atas dikumpulkan dinventarisir, diklasipikasi atau disistematisasikan dan dan diinterpretasikan dan dianalisis, sesuai dengan pemikiran para ahli dan pendapat ahli yang berkembang untuk selanjutnya dianalisis sesuai dengan cita-cita hukum dan fungsi notaris sebagai pejabat umum dan peyandang profesi yang professional.

\section{d.Indikator Capaian}

Indikator capaian penelitian ini ditandai dengan langkah-langkah yang dicapai dalam proses penelitian mengenai Fungsi Klausul Tanggung Jawab Sosial Perusahaan Dalam rangka Pengembangan Perusahaan pad Era Globalisasi. Tahapan pertama berupa teridentifikasi dan terinventarisasinya aspek-aspek . Tahapan capaian ini selanjutnya akan mendukung capaian penelitian berupa tergambarnya inisiasi kebijakan yang perlu dilakukan dalam rangka merumuskan suatu pengembangan hukum perusahaan pada tanggung jawab social.

\section{e.Landasan Konsep}

Klausul Tanggung jawab sosial dan lingkungan sangat memungkinkan dapat dimuat dalam akta notaris baik itu akta pendirian perusahaan maupun perubahan Anggaran Dasar 
dan Anggaran Rumah Tangga Perusahaan yang dapat menjadi agenda dalam Rapat Umum Pemegang Saham (RUPS).

Peran notaris dalam memberikan pandangan kepada perusahaan akan arti penting membuat klausul tanggung jawab sosial menjadi penting dan sangat menentukan, meskipun keputusan untuk menjadikan materi muatan tersebut harus diinginkan pula oleh perusahaan.

Klausul tanggung jawab sosial dan lingkungan perusahaan adalah suatu konsep yang mencantumkan kesadaran akan lingkungan hidup yang baik dan sehat dalam salah satu klausul akta pendirian perusahaan. Klausul tersebut menjadi bagian penting dalam akta Notaris terkait pendirian perusahaan atau perubahan Anggaran Dasar PT sebagai suatu akta autentik yang dapat menjadi dasar dalam pembuktian yang sempurna. Yang dibuat notaris atas kehendak para pihak dan masukan notaris yang berfungsi memberikan penyuluhan hukum akan tanggung jawab hukum dan etis perusahaan guna menyeimbangi kedudukan para pihak termasuk pihak lainnya dalam hal ini lingkungan yang baik dan sehat sebagai bagian untuk keberlangsungan perusahaan dan pembangunan berkelanjutan di Indonesia serta tuntutan era 5.0 sebagai era menikmati hidup dana meretas kesenjngan social masyarakat.

Di sisi lain pemerintah daerah juga dapat mendorongPengembangan Perusahaan Terbatas (PT), yaitu suatu upaya yang dilakukan pemerintah dalam rangka membina PT yang ada, agar dilakukan perubahan dalam Anggaran dasar dan Anggaran Rumah tangga Perusahaan, yang sebelumnya tidak mencantumkan klausul tanggung jawab sosial dan lingkungan perusahaan maka perlu melakukan perubahan agar dalam perbaikannya telah mencantumkan klausul tanggung jawab sosial dan lingkungan. Sekalipun setiap daerah telah memiliki Peraturan Daerah (Perda) tentang tanggung jawab sosial dan lingkungan, 
namun belum ditemukan materi muatan Perda yang mencantumkan adanya perintah untuk mencantumkan Angagaran dasar PT memuat klausul tanggung jawab sosial dan Lingkungan sebagai bagian dari perusahaan bahkan untuk Perda kota jambi hanya focus pada tanggung jawab sosial Perusahaan (TSP), sedangkan di Kota Malang menguakan istilah Tanggung Jawab social dan Lingkungan peerusahaan (TJSLP) ${ }^{5}$.

Globalisasi menuntut peran serta perusahaan dalam menjaga dan memelihara lingkungan, dengan semakin berkembangnya standar-standar lingkungan yang didasar pada prinsip pembangunan berkelanjutan.Tata Kelola perusahaan (Good Corporetae Governance-GCG) merupakan suatu proses struktur BUMN untuk meningkatkan keberhasilan usaha dan akuntabilitas perusahaan jangka panjang dengan memperhatian stakeholders lainnya. Era Globalisasi yang sekarang pouler dengan istilah era industri 4.0 bahkan era 5.0 adalah era yang menyadarkan bahwa bumi ini satu dan diantara stakeholder harus saling menjaga, memelihara agar kesenjangan social dan lingkungan menjadi kesadran hukum bersama untuk menjadikan cetak biru atas lingkungan hidup yang baik dan sehat.

Menurut Habib Adjie, akta yang dibuat oleh Notaris dalam praktek kenotariatan disebut akta relas atau akta berita acara yang berisi uraian Notaris berdasarkan apa yang disaksikan (dilihat dan didengar) oleh notaris sendiri atas permintaan para pihak, agar tindakan atau perbuatan para pihak dituangkan kedalam akta Notaris. ${ }^{6}$ Pieter Latumenten menyebut akta relas sebagai akta pejabat. Dengan demikian akta PT sebagai akta badan hukum adalah akta yang diinginkan oleh para pihak tentang hak dan kewajiban

\footnotetext{
${ }^{5}$ Lihat Perda Nomor 1 Tahun 2016 Kota Jambi Tentang Tanggung Jawab Sosial Perusahaan XIII Bab 26 Pasal, dan Perda Nomor 11 Tahun 2017 Tentang Tanggung Jawab Sosial dan lingkungan Perusahaan terdiri dari XI Bab 45 Pasal, tidak ditemukan Bab tentang kewajiban perusahaan untuk mencantumkan Anggaran Dasar mengenai kewajiban terhadap tanggung jawaba sosial dan lingkungan.

${ }^{6}$ Habib Adjie, Kebatalan dan Pembatalan Akta Notaris, PT Refika Aditama, Bandung, 2011, hlm. 10.
} 
sebagai suatu perjanjian sekaligus anggaran dasar dan keterangan-keterangan lain berkaitan dengan pendirian (Pasal 8 ayat (1) jo Pasal 15 UUPT).Senada dengan dengan Habib Adjie, Pieter menjelaskan Akta pejabat memuat uraian secara otentik dari apa yang disaksikan, dilihat, didengar dan dialami Notaris. ${ }^{7}$ Pada akta relas penandatanganan bukanlah syarat wajib, karena UUJN jo UUJNP memang memperbolehkan itu, namun di dalam akta harus disebutkan alasannya didalam penutup akta.

Akta yang dibuat dihadapan (ten overstaan) notaris, dalam praktek notaris disebut akta pihak, yang menjadi dasar utama atau inti dalam pembuatan akta notaris, yaitu harus ada keinginan atau kehendak (wilsvorming) dan permintaan dari para pihak. Pieter menamakan akta pihak dengan sebutan akta partij atau penghadap, menurutnya, akta patij memuat uraian secara otentik dari apa yang diterangkan oleh penghadap (pihak) kepada Notaris dalam menjalankan jabatannya dan untuk keperluan itu penghadap (pihak) sengaja datang di hadapan Notaris dan memberikan keterangan, agar keterangan penghadap dikonstantir (dinyatakan) dalam akta otentik. Dalam suatu akta partij tanda tangan penghadap merupakan syarat mutlak, karena tanda tangan membuktikan adanya keterangan yang diberikan penghadap. Jika penghadap tak bisa membubuhkan tanda tangan maka harus diterangkan dalam akta alasan apa yang menyebabkan ketidakmampuan membubuhkan tandatangan.

Kemudian dalam pembuatan akta Notaris, kewenangan notaris meliputi empat hal:

1. Notaris harus berwenang sepanjang yang menyangkut akta yang harus dibuat. Wewenang notaris dalam pembuatan akta tidak dikecualikan kepada pihak atau pejabat lain, atau Notaris juga berwenang membuatnya di samping dapat dibuat oleh pihak atau

\footnotetext{
${ }^{7}$ Pierter Latumenten, Cacat Yuridis Akta Notaris Dalam Peristiwa Konkrit Dan Implikasi Hukumnya, TUMA Press, Jakarta, 2011, hlm. 9.
} 
pejabat lain. Hal ini mengandung makna bahwa Notaris memiliki kewenangan yang umum, sedangkan pihak atau pejabat lainnya mempunyai wewenang khusus (terbatas). Jika tindakan Notaris diluar wewenang yang sudah ditentukan, maka dikategorikan sebagai perbuatan di luar wewenang Notaris. Jika hal ini menimbulkan permasalahan dan menyebabkan kerugian materil dan imateril maka dapat diajukan gugatan ke Pengadilan Negeri.

2. Notaris harus berwenang sepanjang mengenai orang untuk kepentingan siapa akta itu dibuat. Meskipun Notaris dapat membuat akta untuk setiap orang, namun untuk menjaga netralitas Notaris dalam pembuatan akta, ada batasannya dalam pasal 52 UUJN, Notaris tidak diperkenankan membuat akta untuk diri sendiri, isteri/ suami atau orang lain yang mempunyai hubungan kekeluargaan dengan Notaris, baik karena perkawinan maupun hubungan darah dalam garis keturunan lurus kebawah dan/ atau ke atas tanpa pembtasan derajat, serta dalam garis kesamping sampai dengan derajat ketiga baik berkapasitas untuk diri sendiri maupun dengan perantara kuasa.

3. Notaris harus berwenang sepanjang mengenai tempat, dimana akta itu dibuat. Pasal 18 ayat (1) UUJN mengatur kedudukan Notaris di satu daerah kabupaten atau kota. Dalam Pasal 19 ayat (1) menentukan bahwa Notaris hanya memiliki satu kantor yakni ditempat kedudukannya. Notaris memiliki wilayah jabatan pada satu provinsi, sehingga notaris diperkenankan membuat akta diluar tempat kedudukannya sepanjang tidak dilakukan secara terus-menerus dan masih berada di wilayah jabatannya dari tempat kedudukannya (Pasal 19 ayat 3 UUJN).

4. Notaris harus berwenang sepanjang mengenai waktu pembuatan akta itu. Notaris dalam menjalankan tugas jabatannya harus dalam keadaan aktif, artinya tidak dalam keadaan cuti atau diberhentikan sementara waktu apalagi diberhentikan selamanya baik secara 
hormat maupun tidak hormat. Notaris yang sedang cuti maka dapat menunjuk notaris pengganti.

Selanjutnya sama-sama telah kita ketahui bahwa akta notaris memiliki kekuatan pembuktian yang sempurna. Fungsi akta yang adalah sebagai alat pembuktian. Akta notaris merupakan alat pembuktian yang sempurna bagi kedua belah pihak dan ahli warisnya serta sekalian orang yang mendapat hak darinya tentang apa yang dimuat dalam akta tersebut. Akta notaris merupakan bukti yang mengikat yang berarti kebenaran dari hal-hal yang tertulis dalam akta tersebut harus diakui oleh hakim, yaitu akta tersebut dianggap sebagai benar selama kebenarannya itu tidak ada pihak lain yang dapat membuktikan sebaliknya. Disinilah letak kesaktian dari sebuah akta Notaris dibandingkan dengan akta dibawah tangan, yakni beban pembuktiannya. Karena akta notaris memiliki kekuatan pembuktian yang sempurna, maka pihak yang menyangkal akta notaris dibebani untuk membuktikan tuduhannya. Oleh sebab itu pihak yang mempergunakan akta notaris tidak perlu mengalami kesulitan membuktikan kebenaran yang termuat dalam sebuah akta notaris. Dengan demikian akta notaris memiliki kekuatan pembuktian:

\section{Lahiriah (uitwendige bewijskracht)}

Kekuatan pembuktian lahariah adalah kemampuan akta itu sendiri untuk membuktikan keabsahannya sebagai akta notaris (acta publica probant sese ipsa). Akta Notaris secara lahiriah harus dianggap sah dan sempurna sampai ada pihak lain yang bisa membuktikan bahwa pembuatan akta tidak sesuai dengan peraturan perundangundangan. Beban pembuktian ini dibebankan pada pihak yang menyangkal keabsahan akta Notaris. Jika pihak lawan berhasil membuktikannya dihadapan persidangan sangkalannya, maka akta Notaris kehilangan nilai pembuktian otentik secara lahiriah.

\section{Formal (Formale bewijskracht)}


Secara formal akta notaris memberikan kekuatan pembuktian otentik pada kepastian tentang pukul, hari, tanggal, bulan, dan tahun pada saat akta dibuat, serta tanda tangan dan paraf dari para pihak, saksi dan Notaris. Jika aspek formal akta ini dipermasalahkan, maka pihak yang menyangkal harus bisa membuktikan ketidak benaran aspek formal tersebut. Bila tidak mampu membuktikan sangkalannya, maka akta tersebut harus diterima oleh siapapun.

\section{Materil (Materiele bewijskracht)}

Merupakan kepastian tentang materi suatu akta, bahwa materi apa yang tertuang dalam akta merupakan pembuktian yang sah terhadap pihak-pihak yang membuat akta atau pihak lain yang mendapat hak dan berlaku untuk umum, kecuali ada pembuktian sebaliknya (tegenbewijs). Keterangan atau pernyataan yang dituangkan dalam akta harus dinilai benar. Jika keterangan yang diberikan oleh para pihak ternyata tidak benar dan dapat dibuktikan oleh pihak yang menyangkal, maka akta kehilangan kekuatan pembuktian materilnya. Selain itu, apabila keterangan tidak benar itu berasal dari para pihak, maka Notaris tidak bisa dipersalahkan atas keterang palsu itu. Namun bila keterangan bohong itu dituangkan notaris atau atas konspirasi bersama dengan pihak lain, maka Notaris ikut bertanggungjawab atas hilangnya kekuatan pembuktian materil dari akta Notaris. Sangkalan atas tidak benarnya materi dari akta itu harus dibuktikan oleh pihak yang menyangkal.

Sebenarnya banyak hal yang bisa dituangkan ke dalam akta Notaris. Menurut Pasal 15 ayat (1) Undang-Undang Nomor 30 Tahun 2004 tentang Jabatan Notaris sebagaimana telah diubah oleh Undang-Undang Nomor 2 Tahun 2014 tentang Perubahan Atas UndangUndang Nomor 30 Tahun 2004 tentang Jabatan Notaris (UUJN), akta notaris bisa memuat semua perbuatan, perjanjian, dan penetapan yang diharuskan oleh peraturan 
perundang-undangan dan/atau yang dikehendaki oleh yang berkepentingan untuk dinyatakan dalam Akta otentik sepanjang pembuatan Akta itu tidak juga ditugaskan atau dikecualikan kepada pejabat lain atau orang lain yang ditetapkan oleh undang-undang.

Salah satu perbuatan hukum yang diharuskan peraturan perundang-undangan untuk dituangkan ke dalam akta Notaris adalah pendirian Perseroan Terbatas (PT). Menurut Pasal 7 ayat (1) Undang-Undang Nomor 40 Tahun 2007 tentang Perseroan Terbatas (UUPT), PT didirikan oleh 2 (dua) orang atau lebih dengan akta notaris yang dibuat dalam bahasa Indonesia. Dalam Akta Pendirian PT, pengaturan mengenai Anggaran Dasar merupakan hal yang utama (lihat Pasal 8 ayat (1) UUPT). Menurut Pasal 15 ayat (1) UUPT, Anggaran Dasar PT setidak-tidaknya memuat 9 (sembilan) hal penting:

1. nama dan tempat kedudukan Perseroan;

2. maksud dan tujuan serta kegiatan usaha Perseroan;

3. jangka waktu berdirinya Perseroan;

4. besarnya jumlah modal dasar, modal ditempatkan, dan modal disetor;

5. jumlah saham, klasifikasi saham apabila ada berikut jumlah saham untuk tiap klasifikasi, hak-hak yang melekat pada setiap saham, dan nilai nominal setiap saham;

6. nama jabatan dan jumlah anggota Direksi dan Dewan Komisaris;

7. penetapan tempat dan tata cara penyelenggaraan RUPS;

8. tata cara pengangkatan, penggantian, pemberhentian anggota Direksi dan Dewan Komisaris;

9. tata cara penggunaan laba dan pembagian dividen.

Selain 9 hal di atas, jika para pendiri bersepakat atau Rapat Umum Pemegang Saham (RUPS) memutuskan untuk memasukan klausul tentang Tanggung Jawab Sosial 
Dan Lingkungan ke dalam Anggaran Dasar PT yang tertuang dalam Akta Notaris, maka hal itu bisa saja dilakukan sebagai komitmen para pendiri atau RUPS untuk mengatur lebih lanjut mengenai apa yang telah diatur dalam Pasal 74 UUPT dan Peraturan Pemerintah Nomor 47 Tahun 2012 tentang ${ }^{8}$ Tanggun Jawab Sosial Dan Lingkungan Perseroan Terbatas (PP 47/2012). Artinya klausul tanggung jawab sosial dan lingkungan (TJSLP) dapat menjadi tambahan dari 9 hal penting di atas

Tanggung Jawab Sosial Dan Lingkungan oleh PT tidak diatur secara lengkap dan jelas oleh UUPT dan PP 47/2012, bila para pendiri PT atau RUPS berkomitmen untuk mengatur Tanggung Jawab Sosial Dan Lingkungan ke dalam Anggaran Dasar yang dituangkan ke dalam Akta Notaris, tentu hal ini akan menjadi tindakan progresif yang patut ditiru oleh PT-PT lainnya. Selain itu, dengan memasukan klausul Tanggung Jawab Sosial Dan Lingkungan ke dalam Anggaran Dasar PT maka komitmen Tanggung Jawab Sosial Dan Lingkungan itu akan menjadi bukti yang sempurna. Kemudian, Anggaran Dasar yang merupakan Konstitusi bagi sebuah PT tentunya akan mengikat bagi siapa saja yang berada di dalam PT.

\section{PEMBAHASAN}

\section{a. Pentingnya Klausul Tanggung Jawab sosial Dan Lingkungan Dalam Akta Notaris.}

Klausul Tanggung jawab sosial dan Lingkungan menjadi penting dan strategis tidak hanya bagi perusahaan tetapi juga dalam pembangunan nasional dan tuntutan terhadap tata kelola perusahaan yang sehat. Di sisi lain dalam pembentukan maupun perubahan perusahaan peranan notaris sebagai pejabat umum tidak dapat dihindari bagi pendiri 
perusahaan, karena berdasarkan UU Nomor 30 Tahun 2004 tentang jabatan notaris yang disempurnakana dengan UU Nomor 2 Tahun 2014 tentang perubahan atas UU Nomor 30 Tahun 2004 tentang jabatan notaris.

Di sisi lain Notaris adalah tugas yang seharusnya merupakan tugas pemerintah,sehingga hasil pekerjaan notaris mempunyai akibat hukum, notaris dibebani sebagian kekuasaan negara dan memberikan pada aktanya kekuatan autentik dan eksekutorial. satu dari beberapa bentuk akta yang harus dibuat di hadapan notaris adalah akta pendirian perseroan terbatas sebagaimana diatur dalam undang-undang nomor 40 Tahun 2007 tentang Perseroan Terbatas (selanjutnya disingkat dengan UUPT Nomor. 40 Tahun 2004).

Pendirian Perseroan Terbatas yang diatur dalam pasal 7 ayat (1) UU No.40 tahun 2004 tentang PT, Merupakan penegasan atas kewenagan notaris yang dipercayakan oleh pemerintah sekaligus wujud dari tugas notaris sebagai pejabat pembuat akta. Kemudian, pasal 15 ayat (1) huruf (i) UU No.40 tahun 2007 mengharuskan anggaran dasar Perseroan Terbatas menyebutkan tata cara penggunaan laba yang diperoleh Perseroan Terbatas tersebut.anggaran dasar Perseroan Terbatas ini harus dicantumkan dalam akta pendirian Perseroan Terbatas yang berisi syarat-syarat fundamental terhadap kepentingan Perseroan Terbatas dan kepentingan pendiri Perseroan Terbatas.

Terkait dengan syarat-syarat fundamental sebagai isi dari akta pendirian perseroan terbatas sebagaimana ditentukan dalam pasal 15 ayat (1) UU No. 40 tahun 2004 tentang PT bahwa Kewajiban Perseroan Terbatas melaksanakan tanggung jawab sosial dan lingkungan sebagai mana ditentukan dalam pasal 74 No. 40 tahun 2004. Dalam pasal 1 angka 3 UU No. 40 tahun 2007 ditegaskan yang dimaksud dengan tanggung jawab sosial lingkungan, yaitu komitmen perseroan untuk berperan serta dalam pembangunan ekonomi berkelanjutan guna meningkatkan kualitas kehidupan dan lingkungan yang bermanfaat, baik bagi perseroan tersendiri, komonitas setempat maupun masyarakat pada umumnya. 
Tanggung jawab sosial dan lingkungan yang disebut juga dengan istilah Corporate Social Responbility (untuk selanjutnya disingkat CSR) adalah hal yang baru diatur dalam UU No. 40 tahun 2007. Oleh karna itu, dengan dibebankannya kewajiban melaksanakan CSR bagi perseroan terbatas menimbulkan reaksi yang pro dan kontra dalam masyarakat, termasuk dikalangan notaris.

Jika program Tanggung jawab sosial dan perusahaan dilaksanakan oleh tiap perseroan terbatas yang beroperasi di Indonesia, terutama kegiatan usahanya yang berkaitan dengan eksplorasi terhadap sumber daya alam, maka tujuan dilaksakannya pembangunan, yaitu mewujudkan masyarat adil dan makmur berdasarkan Pancasila UUD 1945 diharapkan dapat segera tercapai, karena bayak sekali aset sumber daya alam Indonesia yang telah di eksplorasi oleh Perseroan Terbatas, baik dalam maupun luar negeri ${ }^{9}$.

Terkait dengan bentuk badan hukum Perseroan Terbatas, maka eksistensi PT sebagai suatu badan hukum, maka badan hukum itu seperti manusia, menjadi penjelmaan yang benar-benar dalam pergaulan hukum, yaitu suatu badan yang membentuk kehendaknya dengan perantaraan alat-alat atau organ-organ badan tersebut, misalnya anggota-anggotanya atau pengurusnya seperti manusia yang mengucapkan kehendaknya dengan perantaraan mulutnya atau dengan perantaraan tangannya jika kehendak itu di tulis di atas kertas. Apa yang mereka (organen) putuskan, adalah kehendak badan hukum. badan hukum bukanlah suatu hal yang abstrak tetapi benar-benar ada dalam arti badan hukum itu sebagai wujud nyata, akibatnya badan hukum tersebut disamakan atau identik dengan manusia. Badan hukum di anggap identik dengan organ-organ yang mengurus ialah para pengurusnya dan mereka inilah oleh hukum dianggap persoon. ${ }^{10}$

Di sisi lain tanggung jawab sosial perusahaan yang dikembangkan oleh Carol, yang menggambarkan bahwa tanggung jawab social dan lingkungan sebagai suatu piramida yang tersusun dari tanggung jawab ekonomi sebagai landasannya, kemudian tanggung jawab hukum, tanggung jawab etika dan tanggung jawab vilan tropis berada dipuncak piramida. Tanggung jawab ekonomi adalah memperoleh laba untuk kelansungan perusahaan, sebagai perwujudan dari tanggung jawab sosial perusahaan dibidang hukum perusahaan mesti mematuhi hukum yang berlaku sebagai representasi dariaturan yang ada. Tanggung jawab sosial juga harus tercermin dari prilaku etis perusahaan dan puncaknya adalah tangung jawab vilan tropis yang mengharuskan perusahaan untuk mengkontribusi terhadap komunitasnya yaitu meningkatkan kualitas hidup.

\footnotetext{
${ }^{9}$.Andreas Pramudianto,(2017) Hukum Lingkungan Internasional, Rajawali Pers, Depok hlm 4
} 
Dengan demikian peranan perusahaan, sebagai hak dan kewajiban tertentu dari suatu kedudukan tertentu. Suatu hak sebenarnya merupakan wewenang untuk berbuat atau tidak berbuat, sedangkan kewajiban adalah beban atau tugas. Peranan hukum dalam melaksanakan fungsinya dalam masyarakat salah satunya adalah sebagai bentuk pengubahan tata tertib dan aturan-aturan dalam rangka penyusaian pada kebutuhan-kebutuhan dari masyarakat, agar dapat memenuhi tuntutan keadilan, hasil guna (doelmatigheid) adalah aspek materi yang ditujukan dalam tujuan kegunaan dari hukum kepentingan sosial. PT dalam hal ini dapat dimknai sebagai setiap bentuk usaha yang menjalankan setiap jenis usaha yang bersifat tetap dan terus-menerus dan yang didirkan bekerja serta berkedudukan dalam wilayah negara Republik Indonesia, untuk tujuan memperoleh keuntungan dan/atau laba”. kepentingan mencari laba atau keuntungan ekonomi merupakan inti dari perusahaan yang kegiatannya dilakukan secara terus-menerus dan terang-terangan dengan mempergunakan organisasi produksi. Tujuan umum tersebut pada prakteknya harus diwujudkan dalam berbagai jenis usaha perusahaan. Untuk perseroan terbatas (PT) jenis kegiatan usaha disebutkan dalam Anggaran Dasarnya.

Berdasarkan Pasal 1 UU No. 40 Tahun 2007 tentang PT, bahwa PT merupakan“badan hukum yang merupakan persekutuan modal, didirikan berdasarkan perjanjian, melakukan kegiatan usaha dengan modal dasar yang terbagi dalam saham dan memenuhi persyaratan yang ditetapkan dalam undang-undang ini serta aturan pelaksanaanya".Ketentuan Pasal 1 UU No. 40 Tahun 2007 ini menambahkan bahwa perseroan adalah badan hukum yang merupakan persekutuan modal. Sedangkan sebagai hukum perseroan, juga merupakan tempat para pihak melakukan kerja sama,yaitu melakukan hubungan kontraktual. Kerja sama ini menciptakan badan hukum yang sengaja diciptakan, yaitu perseroan sebagai suatu "artifical person". Tanggung jawab sosial dan lingkungan, adalah tanggung jawab sosial dan lingkungan menurut Pasal 1 ayat (3) UU No. 40 Tahun 2007, yaitu :“ komitmen perseroan untuk berperan serta dalam pembangunan ekonomi berkelanjutan guna meningkatkan kualitas kehidupan dan lingkungan yang bermanfaat, baik bagi perseroan sendiri, komunitas setempat maupun masyarakat pada umumnya".

Tanggung jawab sosial dan lingkungan, berdasarkan Pasal 74 UU No. 40 Tahun 2007 menegaskan, sebagai berikut : “Perseroan terbatas yang menjalankan legiatan usahanya di bidan dan/atau berkaitan dengan sumber daya alam, wajib melaksanakan tanggung jawab sosial dan 
lingkungan, yang merupakan kewajiban perseroan yang dianggarkan dan diperhitungkan sebagai biaya perseroan yang pelaksanaanya dilakukan dengan memperhatikan kepatutan dan kewajaran”.

Selanjutnya, menurut penjelasan atas Pasal 15 huruf b UU No. 25 tahun 2007 tentang penanaman modal, tanggungjawab sosial perusahaan, adalah: " Tanggung jawab yang melkat pada setiap perusahaan penanaman modal untuk tetap menciptakan hubungan yang serasi,seimbang dan sesuai dengan lingkungan,nilai,norma dan budaya masyarakat setempat. Sedangkan yang dimaksud dengan Notaris, adalah "Pejabat umum yang berwenang untuk membuat akta autentik dan kewenangan lainya sebagaimana yang dimaksud dengan Udangundang ini'.Dokumen yang dibuat notaris dalam hukum telah diberikan dalam kekuatan khusus sesuai dengan buku ke empat KUH perdata pada pasal 1867 dan seterusnya mengenai akta autentik.Notaris diberi kewenangan untuk membuat akta autentik yang hakikatnya memuat kebenaran formal sesuai dengan apa yang diberitahukan para pihak, diharapkan akta yang dibuat notaris mampu menjamin kepastian,ketertiban dan perlindungan hukum.Notaris juga mempunyai kewajiban untuk memasukan apa yang termuat dalam akta notaris sungguh-sungguh telah dimengerti dan sesuai dengan kehendak para pihak, serta memberikan akses terhadap peraturan perundang-undangan yang terkait bagi para pihak penandatanganan akta. Akta otentik adalah menurut pasal 1868 KUH Perdata, yaitu:"Suatu akta yang dibuat dalam bentuk yang ditentukan undang-undang atau dihadapan pejabat umum yang berwenang untuk itu ditempat akta itu dibuat".

Terkait dengan akta otentik, dapat dijelaskan bahwa akta otentik dibagi menjadi dua jenis yaitu:

a. Proses verbal akta,yaitu akta yang dibuat oleh pejabat umum (akta pejabat ,acte ambtelijk,relas akta) merupakan akta yang telah dibuat oleh pejabat (dalam jabatannya), atas segala apa yang dilihat, didengar dan disaksikan .Akta pejabat tidak termasuk dalam pengertian kontrak karena akta ini merupakan pernyataan sepihak dari pejabat, contohnya akta kawin, akta lelang dan alin-lain.

b. Partij akta (akta partai ,akta para pihak), yaitu akta otentik yang dibuat oleh para pihak,dinyatakan di depan pejabat yang berwenang. Pejabat yang berwenang itu adalah Notaris,Pejabat Pembuat Akta Tanah (PPAT) dan lainnya. ${ }^{13}$ 
Akta Notaris merefleksikan perjanjian yang mengikat para pihak yang membuatnya. Oleh karena itu,syarat-syarat sahnya perjanjian harus dipenuhi sebagaimana ditentukan dalam pasal 1320 KUH perdata,yang terdiri dari syarat subyektif,yakni syarat yang berkaitan dengan subyek yang mengadakan atau membuat perjanjian,yang terdiri atas kata sepakat dan cakap bertindak untuk melakukan suatu perbuatan hukum,dan syarat obyektif, yakni syarat yang berkaitan dengan perjanjian itu sendiri atau berkaitan dengan obyek yang dijadikan perbuatan hukum oleh para pihak yang terdiri dari suatu hal tertentu dan sebab yang terlarang.

Berdasarkan syarat di atas maka pemuatan klausul tanggung jawab sosial dan lingkungan, menjadi materi kewajiban tanggung jawab social dan lingkungan dapat dimulai sebagai syarat subyek yang membuat perjanjian berupa kata sepakat yang dipandang cakap bertindak dalam memastikan masyarakat akan obyek tertentu yakni penyisihan keuntungan dengan persentasi tertentu untuk kegiatan keadilan lingkungan sebagai kesadaran hukum dan kesadaraan etis perusahaan dalam mengimlementasikan pembangunan berkelanjutan.

\section{b.Peran Perusahaan Dalam Pembangunan Berkelanjutan dalam kewajiban hukum dan moral terhadap Klausul Tanggung Jawab Sosial dan Lingkungan pada Akta Pendirian dan Perubahan Perseroan Terbatas (Anggaran dasar)}

Perkembangan perusahaan yang sangat dinamis tentu harus di dorong oleh berbagai stakeholder untuk mengembangkan hukum baik dalam tataran hukum dan doktrin yang terus berkembang dalam mewujudkan suatu tujuan negara yakni masyarakat adil dan makmur. termasuk notaris memberikan andil yang sangat besar pada terwujudnya Indonesia sebagai Negara hukum yang mengedepankan prinsip-prinsip pembangunan berkelanjutan.

Fakta menunjukkan bahwa meningkatnya aspek kuantitas orang untuk mendirikan perusahaan tentu harus harmonis dengan penataan ruang dan aspek daya guna dan hasil guna perusahaan dalam perwujutan Indonesia sebagai Negara hukum yang berdaulat penuh atas sumber daya alam yang ada untuk menjaga dana melestarikannya ${ }^{11}$

11 .Elita Rahmi, Intrumen Pemberian Izin Lokasi Perkebunan Sawit Dalam Rencana Tata Ruang Provinsi Jambi,(Jurnal penelitian Universitas Jambi, Seri Humaniora.Volume 14 Nomor 1 Januari-Juni 2012.ISSN 0852-8349. 
Pasal 1869 KUH Perdata menetukan batasan akta notaris yang mempunyai kekuatan pembuktian sebagai akta di bawah tangan dapat terjadi jika tidak memenuhi ketentuan,karena tidak berwenangnya pejabat umum yang bersangkutanatau cacat dalam bentuknya. Meski demikian ,akta seperti tersebut tetap mempunyai kekuatan hukum pembuktian sebagai akta di bawah tangan, jika akta tersebut ditanda tangani oleh para pihak.

Secara tertulis,memang tidak ada aturan hukum yang mengatur secara tegas bahwa klausula tanggung jawab social dan lingkungan (TJSLP) harus dimasukan dalam Angaran Dasar Perseroan Terbatas.Namun,jika ditinjau dari sifat norma hukumnya bahwa TJSLP bersifat wajib bagi Perseroan Terbatas yang akan menjalankan kegiatan usaha yang berkaitan dengan sumber daya alam, artinya ada paksaan untuk melaksanakan TJSLP bagi Perseroan Terbatas tersebut.

Selanjutnya,jika ditinjau dari implikasi hukum laporan TJSLP , dapat dicermati dalam pasal 66 ayat (2) UU No.40 Tahun 2007 menegaskan bahwa laporan tahunan Rapat Umum Pemegang saham (RUPS) sekurang-kurangnya memuat antara lain adalah mengenai tanggung jawab sosial dan lingkungan. Jadi, TJSLP merupakan hal penting yang pada akhirnya harus dilaporkan dalam RUPS sebagai laporan keuangan perseroan.

Akta Notaris merupakan tanda-tanda pernyataan kaedah hukum yang berwujud.Pernyataan terhadap kaedah hukum berwujud tertulis ini menurut Soerjono Soekanto harus dinyatakan secara jelas dan terang. Sehubungan dengan ini,seharusnya TJSLP dalam akta pendirian yang memuat Anggaran Dasar Perseroan Terbatas sebagai bentuk pernyataan terhadap kaedah hukum yang tegas dan terang, dengan alasan-alasan, sebagai berikut:

a) Pedoman bagi Perseroan dalam menjalankan kegiatan usahanya

b) Komitmen Perseroan Terbatas dalam me;aksanakan apa yang sudah diamanatkan dalam pasal 74 UU No.40 tahun 2007

c) Pelaksanaan pasal 15 ayat (1) huruf i UU No. 40 tahun 2007 yang menyatakan bahwa Anggaran Dasar Perseroan sekurang-kurangnya memuat tentang tata cara penggunaan laba dan pembagian deviden.

Konsep TJSLP di berbagai negara asing, terutama negara-negara industri maju, dianggap sebagai sebuah konsep yang berdimensi etis dan normal, sehingga pelaksanaannya pun oleh perusahaan pada prinsipnya bersifat sukarela,bukan sebagai suatu kewajiban hukum. Di indonesia 
konsep TJSLP justru dijadiakan sebagai sebuah kewajiban hukum yang harus di patuhi oleh perusahaan, sebagaimana ditegaskan dalam pasal 74 ayat (1) UU No.40 Tahun 2007.

Menurut Mahkamah Konstitusi, TJSLP merupakan suatu kewajiban hukum yang ditentukan dalam pasal 74 UU No.40 Tahun 2007 sebagai kebijakan hukum dari pembentuk undang-undang untuk mengatur dan menerapkan TJSLP dengan suatu sanksi dan ini adalah benar, karena:

a) Secara faktus, kondisi lingkungan telah rusak dimasa lalu ketika perusahaan mengabaikan aspek sosial dan lingkungan pada umumnya

b) Budaya Hukum Indonesia tidak sama dengan negara industri maju tempat konsep CSR pertama kali diperkenalkan, dimana TJSLP bukan merupakan tuntutan bagi perusahaan kepada masyarakat dan lingkungannya, tetapi juga telah dijadikan sebagai salah satu indikator kinerja perusahaan dan syarat bagi perusahaan yang akan go public. Artinya Mahkamah Konstitusi berpendapat bahwa sesuai kultur hukum indonesia, penormaan TJSLP sebagai norma hukum yang diancam dengan sanksi hukum merupakan suatu keharusan demi tegaknya TJSLP.

UU No.30 tahun 2004 telah mengatur sanksi kepada Notaris yang talah menyimpang dari UU No.30 Tahun 2004 dan Kode Etik Notaris. Dalam Pasal 84 UU No.30 Tahun 2004 dinyatakan bahwa tindakan pelanggaran yang dilakuakn oleh notaris terhadap ketentuan sebagaimana yang dimaksud dalam Pasal 16 ayat (1) huruf i, Pasal 16 ayat (1) huruf k, Pasal 41, Pasal 44, Pasal 48, Pasal 49, Pasal 50, Pasal 51, Pasal 52, yang mengakibatkan suatu akta hanya mempunyai kekuatan pembuktian sebagai akta dibawah tangan menjadi batal demi hukum dapat menjadi alasan bagi pihak yang menderita kerugian untuk menuntut penggantian biaya, ganti rugi dan bunga kepada notaris.

Selanjutnya, dalam Pasal 85 UU No.30 tahun 2004 dinyatakan bahwa pelanggaran terhadap ketentuan pasal 7, pasal 16 ayat (1) huruf a, pasal 16 ayat (1) huruf b, pasal 16 ayat (1) c, pasal 16 ayat (1) d, pasal 16 ayat (1) e, pasal 16 ayat (1) f, pasal 16 ayat (1) g, pasal 16 ayat (1) h, pasal 16 ayat (1) i, pasal 16 ayat (1) j, pasal 16 ayat (1) k, pasal 17, pasal 20, pasal 27, pasal 32, pasal 37, pasal 54, pasal 58, dan pasal 59 dan/atau pasal 63 dapat dikenalia Teguran lisan,Teguran 
tertulis,Pemberhentian sementara,Pemberhentian dengan hormat; atau Pemberhentian dengan tidak hormat

Menurut Kode Etik Notaris, khususnya Pasal 1 angka 12, sanski adalah Suatu hukum yang dimaksudkan sebagai sarana, upaya dan alat pemaksa ketaatan dan disiplin anggota Perkumpulan maupun orang lain yang memangku dan menjalankan Jabatan Notaris, dalam menegakkan kode etik dan disi[lin organisasi."

Pasal 3 angka 4 Kode Etik Notaris, yang menyatakan bahwa Notaris harus bertindak jujur, mandiri dan tidak berpihak, penuh rasa tanggung jawab berdasarkan peraturan perundangundangan dan isi sumpah jabatan notaris. Jika rumusan ini dikaitkan Pasal 7 ayat (1) UU No.40 tahun 2007 mengenai pendirian perseroan terbatas dan pasal 15 ayat (1) huruf i UU No.40 tahun 2007 mengenai hal-hal yang harus dicantumkan dalam anggaran dasar perseroan terbatas sekurang-kurangnya memuat mengenai tata cara penggunaan laba dan pembagian deviden, serta ketentuan pasal 74 UU No.40 tahun 2004 yang mewajibkan perseroan yang menjalankan kegiatan usahanya yang berkaitan dengan sumber daya alam, maka secara etika dengan berlandasan pada interpretasi ketentuan peraturan tersebut di atas, notaris seharusnya memasukan klausul CSR dalam akta pendirian Perseroan Terbatas.

Kemudian, dalam Pasal 3 angka 6 Kode Etik Notaris yang menyatakan bahwa mengutamakan pengabdian kepada kepentian masyarakat dan negara, berarti Notaris dituntut untuk dapat memahami apa yang diinginksn oleh negara dalam hal ini melalui peraturan perundangundangan, khususnya UU No.40 tahun 2007 dapat sampaikan kepada masyarakat, sehingga masyarakat diharapkan dapat memahami dan melaksanakan apa yang telah ditentukan oleh negara.

Apabila Notaris berperan sebagai pejabat umum yang diberi kewenangan untuk membuat akta otentik serta peranannya antara lain adalah membuat akta otentik dan sebagai penyuluh hukum tidak melaksanakan peranannya tersebut secara profesional seperti dalam hal memasukan klausul CSR kedalam anggaran dasar perseroan terbatas yang menjalankan kegiatan usahanya di bidang yang berkaitan dengan sumber daya alam, tentu hal ini dapat dianggap bahwa Notaris tersebut telah menyalahi Kode Etik Notaris sebagaimana yang dirumuskan dengan pasal 3 angka 4 dan angka 6 di atas, yang dapat dikenakan sanksi berupa sanksi administratif sebagaimana dirumuskan dalam pasal 6 Kode Etik Notaris, yaitu: Sanksi yang dikenakan terhadap anggota yang melakukan pelanggaran kode etik dapat berupa :Teguran, Peringatan, Schorsing (pemecatan 
sementara) dari keanggotaan perkumpulan,Pemberhentian dengan tidak hormat dari keanggotaan perkumpulan. Penjatuhan sanksi-sanksi sebagaimana teruarai diatas terhadap anggota yang melanggar Kode Etik disesuaikan dengan kuantitas dan kualitas pelanggaran yang dilakukan anggota tersebut.

Jenis dan bentuk sanksi yang akan dijatuhkan kepada Notaris yang tidak memasukan klausul TJSLP dalam Anggaran Dasar Perseroan Terbatas, menjadi wewenang dari Majelis Pengawas, dengan berpedoman pada ketntuan-ketentuan dalam UU No. 30 Tahun 2004 dan peraturan pelaksanaanya. Jadi, ditinjau dari nilai adan asas sebagai penegak hukum, Notaris harus dapat menegakkan hukum itu sendiri, dalam hal ini adalah Pasal 74 UU No.40 Tahun 2007. Oleh karena itu, Notaris yang tidak memuat klausul TJSLP dalam anggaran dasar Perseroan Terbatas dapat dianggap melanggar Kode Etik Notaris, dan untuk itu terhadap Notaris tersebut dapat dimintakan pertanggung-jawabannya secara profesi dihadapan Majelis Pengawas setempat di wilayah kantor dimana Notaris tersebut menjalankan aktivitas profesi-nya sebagai Notaris.

\section{KESIMPULAN}

a. Fungsi Notaris sebagai Pejabat Umum dalam menjalankan tugasnya wajib memberikan pemahaman kepada perusahaanuntuk menjadikan klaususl tanggung jawab sosial dan lingkungan dalam akta pendirian Perseroan Terbatas yang menjalankan kegiatan usahanya dengan lingkungan dengan sumber daya alam adalah sebagai bentuk penegakan sistem hukum, yang tujuannya adalah utuk mempermudah meminta pertanggung jawaban Perseroan Terbatas dalam Pelaksanaan CSR, sebagai amanah Pasal 15 ayat 910 huruf i, Pasal 70, dan Pasal 74 UU No.40 Tahun 2007 dan sebagai bentuk komitmen Perseroan Terbatas dalam berperan serta secara aktif pelaksanaan tanggung jawab sosial dan lingkungan.

b. Konsekwensi hukum bagi akta pendirian yang belum memuat Anggaran Dasar Peseroan Terbtas dan tidak mencamtumkan klausul tanggung jawab sosial dan lingkungan, adalah bertentangan dengan Pasal 74 UU No.40 Tahun 2007 yang mengarahkan Notaris untuk membuat klausul tanggung jawab sosial dan lingkungan dalam anggaran dasar Perseroan Terbatas. Karena UU No. 40 tahun 2007 cukup tegas mengaturnya , maka sanksi kepada Notaris yang belum memuat klausul CSR dalam anggaran dasar Perseroan Terbatas adalah sanksi hukum dan 
moral, karena Notaris dianggap melanggar UU PT dan Kode Etik Notaris. Adapun bentuk dan jenis sanksi yang akan dijatuhkan kepada Notaris tersebut merupakan wewenang Majelis Pengawas Notaris untuk diperingati secara tertulis dan dipertegas dngan pengawasan pemerintah dalam perizinan lainnya sebelum operasionala perusahaan.

\section{Saran}

a. Kepada Ikatan Notaris Indonesia (INI) hendaknya terus melakukan upaya sosialisasi kepada anggota INI mengenai semua peraturan-peraturan perundangundangan yang ada, sehingga diharapkan pemahaman akan apa yang dikehendaki oleh undang-undang dapat disampaikan oleh Notaris yang juga berperan sebagai penyuluh hukum.

b. Kepada pemerintah daerah perda tentang tanggung jawab sosial dan lingkungan juga mencantumkan norma tentang kewajiban hukum untuk memuat klausul tanggung jawab sosial dan lingkungan dalam anggaran dasar PT.

c. Kepada Kemenkumham untuk dapat menyempurnakan standar akta PT bagi pedoman notaris

d. Kepada Ikatan Notaris Indonesia (INI) senantiasa mengembangkan kode etik notaris sesuai dngan kebutuhan global bahwa produksi tidak hanya keuntungan semata tetapi juga kualitas menjaga lingkungan hidup yang baik da sehat,

e. Kepada notaris dapat mengembangkan hukum melalui akta notaris yang dikeluarkan dengan menumbuhkan kesadaran akan lingkungan hidup yang baik dan sehat atau pembangunan berkelanjutan sebagai kewajiban perusahaan dan sebagai etika dalam berbisnis yang sehat di era globalisasi.

f. Hendaknya dalam Kode Etik Notaris dirumuskan dan dijelaskan secara terperinci jenis-jenis pelanggaran dan mekanisme pengenaan sanksi, terutama sanksi dalam mencari dan mencapai keadilan bagi Notaris itu sendiri.

\section{Daftar Pustaka}




\section{Buku :}

Adjie, Habib. Status Badan Hukum, Prinsip-prinsip dan Tanggung Jawab Sosial Perseroan Terbatas. Mandar Maju Bandung 2008.

Andreas Pramudianto,. Hukum Lingkungan Internasional, Rajawali Pers, Depok, Jakarta 2017

Bachsan Mustafa, Sistem Hukum Indonesia Terpadu Citra Aditya Bakti Bandung 2016

Ginting, Jamin. Hukum Perseroan Terbatas. Citra Aditya Bakti Bandung 2007

Herlien Budiono,Kumpulan Tulisan Hukum Perdata di bidang Kenotariatan Buku Kesatu, Citra Aditya Bakti, Bandung 2015

-,Kumpulan Tulisan Hukum Perdata di bidang Kenotariatan Buku Kedua, Citra Aditya Bakti, Bandung 2015

,Kumpulan Tulisan Hukum Perdata di bidang Kenotariatan Buku Ketiga, Citra Aditya Bakti, Bandung 2015

Maret Priyanta, Pengelolaan Hutan Berkelanjutan (Dalam Kerangka Pembaharuan Sistem Hukum Lingkungan dan Tata Ruang Berbasis Perubahan Iklim), Logoz Publishing, Bandung 2018

Natabaya, A.S. 2006. Sistem Peraturan Perundang-undangan Indonesia. Sekretariat Jendral dan Kepaniteraan Mahkamah Konsistusi.Jakarta 2006

Simanjuntak, Cornelius dan Natalie Mulia. Organ Perseroan Terbatas. Jakarta: Sinar Grafika.Jakarta 2009

Sjaifurrachman, 2011. Habib Adjie, Aspek Pertanggungjawaban Notaris Dalam Pembuatan Akta, Mandar Maju Bandung

\section{Jurnal Ilmiah:}

Adjie, Habib. 2008. “ Tanggung Jawab Sosial Perusahaan”. Jurnal Hukum Bisnis. No.1. Volume 27.

Chairil N. Siregar, Analisis Sosiologis Terhadap Implementasi Corporate Social Responsibility Pada masyarakat Indonesia, Jurnal Sosiateknologi Institut Teknologi Bandung (ITB)

Elita Rahmi, Standarisasi Lingkungan (ISO 26000) Sebagai Harmonisasi Tanggung Jawab Sosis1 Perusahaan dan Intrumen Hukum Indonesia,Inovatif Jurnal Ilmu HUkum, Vol 4 No 5 (2011).

,Intrumen Pemberian Izin Lokasi Perkebunan Sawit Dalam Rencana Tata Ruang Provinsi Jambi,(Jurnal penelitian Universitas Jambi, Seri Humaniora.Volume 14 Nomor 1 Januari-Juni 2012.ISSN 0852-8349. 
Herlien Budiono, Arah Pengaturan UndangUndang Nomor 40 Tahun 2007 Tentang Perseroan Terbatas Dalam menghadapi Era Global, (Jurnal Rechtsvinding Volume 1 Nomor 2 Agustus 2012.Jurnal pada Pembinaan Hukum Nasional kementerian Hukum dan HAM RI.ISSN 2089-9009.

Ida Bagus Paramaningrat Manuaba, I Wayan Parsa, I Gusti Ketut Ariawan, Prinsip Kehati-hatian Notaris Dalam membuat Akta Autentik, Jurnal Acta Comitas Jurnal Huku Kenotariatan Universitas Udayana. Bali (2018)1:59-74.ISSN 2502-8960 I e-ISSN:2502-7573.

Yulia Setyarini,Melvie Paramitha, Pengaruh Mekanisme Good Corporate Governance Terhadap Corporate Social Responsibility, Jurnal Kewirausahaan Volume 5 Nomor 2,Lembaga penelitian dan pengabdian Masyarakat Universitas Widya Kartika Surabaya.ISSN 19784724

Peraturan Perundang-Undangan

Perda Kota Jambi Nomor 1 Tahun 2016 Tentang Tanggung Jawab Sosial Perusahaan.Lembaran Daerah Kota Jambi Tahun 2016 Nomor 1

Perda Magelang Provinsi Jawa tengah Perda Nomor 11 Tahun 2017 Tentang Tanggung Jawab Sosial dan lingkungan Perusahaan

UndangUndang Nomor 40 Tahun 2007 Tentang Perseroan Terbatas (Lembaran Negara RI Tahun 2007 Nomor 106. Tambahan lembaran Negara RI Nomor 4756)

.UndangUndang Nomor 32 Tahun 2009 Tentang PerlindUngan dan pengelolaan Lingkungan Hidup(Lembaran Negara RI Tahun 2009 Nomor 140, TLN RI Nomor 5059

UndangUndang Nomor 2 Tahun 2014 Tentang Perubahan Atas UU Nomor 30 Tahun 2004 Tentang Jabatan Notaris (Lembaran Negara RI tahun 2014 Nomor 3, TLN RI Nomor 5491. 
